\title{
Analisis Penerimaan Layanan Cloud Google Apps for Education pada Jurusan Teknik Komputer dan Informatika Politeknik TEDC Bandung
}

\author{
Karina Dhena Goda \\ Sistem Informasi Bisnis- STMIK LIKMI Bandung \\ Jl. Ir. H.Djuanda No.96 Bandung-Jawa Barat - Indonesia \\ Karyn.goda@gmail.com
}

\begin{abstract}
Abstrak - Perkembangan di bidang komputasi telah melahirkan berbagai layanan yang memberikan kemudahan dan manfaat bagi pengguna. Komputasi dengan akses yang terbatas sebelumnya kini telah berevolusi menjadi layanan komputasi dengan kemampuan akses yang luas karena dikolaborasikan dengan layanan internet menjadi sebuah layanan komputasi berbasis cloud (cloud computing). Layanan Software as a Service merupakan salah satu dari tiga layer utama dalam layanan cloud computing yang menyediakan layanan software siap pakai bagi pengguna. Dalam penelitian ini, penulis tertarik untuk menganalisis penerimaan mahasiswa Jurusan teknik Komputer dan Informatika Politeknik TEDC terhadap layanan software as a Service Google Apps berbasis Cloud Computing dengan menggunakan Model Technology Acceptance Model (TAM).

Populasi dalam penelitian ini adalah mahasiswa jurusan Teknik Komputer dan Informatika Politeknik TEDC Bandung. Penentuan sampel dilakukan dengan teknik Simple Random Sampling dengan memberikan peluang yang sama bagi setiap anggota populasi untuk menjadi sampel. Teknik pengolahan data dilakukan dengan Structural Equation Modeling (SEM) yang dibantu aplikasi SPSS AMOS versi 22.

Hasil Penelitian tentang analisis penerimaan mahasiswa terhadap layanan Software as a Service Google Apps berbasis cloud computing pada jurusan Teknik Komputer dan Informatika menunjukkan bahwa: Perceived Ease of Use berpengaruh signifikan terhadap Perceived Usefulness, Perceived Usefulness berpengaruh signifikan terhadap Intention to Use, Perceived Ease of Use tidak berpengaruh signifikan terhadap Intention to Use, System Quality berpengaruh signifikan terhadap Perceived Usefulness, Relative Advantage berpengaruh signifikan terhadap Perceived Usefulness, Trust tidak berpengaruh signifikan terhadap Perceived Usefulness, Compatibility tidak berpengaruh signifikan terhadap Perceived Usefulness, Compatibility tidak berpengaruh signifikan terhadap Perceived Ease of Use, Job relevance berpengaruh signifikan terhadap Perceived Usefulness, Job Relevance berpengaruh signifikan terhadap Perceived Ease of Use, User Interface Design berpengaruh signifikan terhadap Perceived Ease of Use dan Experience berpengaruh signifikan terhadap Perceived Ease of Use.
\end{abstract}

Kata Kunci- Software as a Service, Cloud Computing, Google Apps, Technology Acceptance Model (TAM), Structural Equation Model (SEM).

\section{PENDAHULUAN}

Kemajuan teknologi yang semakin pesat terutama perkembangan jaringan internet yang semakin luas telah menciptakan berbagai layanan yang memberikan kemudahan bagi pengguna, terutama dalam mengatasi keterbatasan ruang dan waktu. Kemudahan akses di mana dan kapan saja menjadi layanan yang paling banyak dicari. Layanan berbasis internet yang sedang berkembang pesat saat ini adalah layanan komputasi awan atau dikenal dengan istilah cloud computing. Selama beberapa tahun terakhir, teknologi komputasi berbasis cloud atau cloud computing telah memberi dampak luar biasa terhadap perkembangan teknologi dan informasi. Cloud computing masuk dalam daftar tren teknologi strategis tahun 2012 berdasarkan survey oleh Gartner [1], bahkan sampai tahun 2015 cloud computing masih masuk dalam daftar 10 teknologi strategis [2]. Dalam Tribuntechno , kepala devisi data center PT Indosat, Gidion Suranta Barus mengatakan bahwa penerapan cloud computing telah menjadi solusi yang fleksibel dan aman dengan pencapaian tingkat efektifitas $77 \%$ dan waktu lebih cepat $72 \%$. Keandalan juga bisa ditingkatkan $50 \%$ [3]

Salah satu layanan yang ditawarkan dalam cloud computing adalah layanan Software as a Service (SaaS) yang memungkinkan pengguna untuk menggunakan perangkat lunak yang telah disediakan oleh cloud provider. SaaS dapat diakses dari jarak jauh (remote) oleh penggunanya dengan menggunakan internet dari berbagai jenis perangkat klien melalui sistem antarmuka [4]. Salah satu perusahaan yang menawarkan layanan SaaS adalah Google dengan layanan Google Apps. Google Apps merupakan aplikasi berbasis cloud yang menawarkan berbagai jenis aplikasi di dalamnya dan Google telah mengkomersikan beberapa layanan Google Apps sebagai layanan enterprise berbasis cloud (Sosinsky, 2011:164). Namun, beberapa layanan lainnya dapat digunakan secara gratis. Semua aplikasi dalam Google Apps dapat berkolaborasi antar akun, mulai dari pengolahan dokumen pada Google Docs, sharing jadwal melalui kalender, sharing dengan hangout dan lainnya. Google Apps memberikan banyak kemudahan bagi pengguna. Menurut Pepita Gunawan, Indonesian Education Lead for Google Southeast Asia, dalam 
seminar Google Apps for Education di Universitas Brawijaya Malang, dikutip dari www.techno.kompas.com mengatakan bahwa keberadaan Google Apps khususnya di bidang pendidikan membantu menajamkan pemikiran kritis [6].

Adanya pengembangan layanan telah melahirkan sikap penerimaan dan penolakan dalam proses penggunaannya. Layanan SaaS Google Apps berbasis cloud computing yang penggunaannya relatif diterima oleh pengguna akan meningkatkan nilai layanan.

\section{LANDASAN TEORI}

\section{A. Cloud Computing}

Cloud computing pada dasarnya adalah layanan berbasis internet untuk mendukung proses bisnis. Kata "Cloud" merujuk pada simbol awan yang dalam teknologi informasi melambangkan jaringan internet. Secara sederhana cloud computing dapat diartikan sebagai teknologi yang menggunakan layanan yang disediakan oleh provider dengan basis internet. Cloud computing merupakan kumpulan dari beberapa sumber daya komputasi yang terintegrasi sehingga menjadikannya sebagai layanan yang mempunyai skalabilitas tinggi (Meruvian, 2012:3). Dari prespektif pemasaran, Rajkumar Buyya mendefinisikan cloud computing sebagai sistem komputasi paralel dan terdistribusi yang dikombinasikan oleh kelompok mesin virtual dan internal link (Qi \& Gani, 2014:2).

Konsep yang diterima secara luas dikemukakan oleh Mell dan Grance dari National Institute of Standards and Technology (NIST) Information technology Laboratory yang menguraikan cloud computing dari tiga sudut pandang karakteristik, model layanan dan model pengembangan.

\section{B. Layanan Software as a Service}

Software as a Service (SaaS) sebagai sebuah paket layanan aplikasi dari provider dimana pengguna dapat langsung menggunakan berbagai fitur yang disediakan oleh penyedia layanan melalui internet. Hanya saja dengan konsep SaaS ini, pelanggan tidak memiliki kendali penuh atas aplikasi yang disewa. Sasaran utama layanan Software as a Service ini adalah pengguna aplikasi teknologi informasi.

\section{Google Apps}

Google Apps adalah sebuah layanan yang menyediakan secara terpisah versi-versi yang dapat disesuaikan dari beberapa produk Google di bawah nama domain sendiri [9]. Google Apps merupakan layanan software as a service yang milik Google yang dibagi menjadi beberapa kelompok layanan berdasarkan kebutuhan penggunanya seperti Google Apps for Work, Google Apps for Government,Google Apps for Education, Google untuk lembaga nonprofit dan lainya. Salah satu manfaat yang paling menonjol dengan penggunaan Google Apps adalah bahwa pengguna tidak memerlukan staf IT karena Google akan mengambil alih segala masalah teknis yang timbul.

\section{Technology Acceptance Model}

Technology Acceptance Model (TAM) bertujuan untuk menganalisis dan memahami faktor-faktor yang mempengaruhi penerimaan teknologi, diantaranya tercatat dalam berbagai referensi hasil riset dibidang teknologi seperti Theory of reasoned Action (TRA), Theory of Planned Behaviour (TPB) dan Technology Acceptance Model (TAM) [10]. Tujuan model TAM adalah untuk menjelaskan faktorfaktor utama dari pelaku pengguna terhadap penerimaan teknologi. Model ini menempatkan faktor sikap pengguna dengan dua variable yaitu kemudahan penggunan (ease of use) dan kemanfaatan (usefulness).

\section{E. Model Penelitian}

Model penelitian ini mengadopsi model penelitian yang dilakukan oleh Venkatesh dan Davis [11] dan dikembangkan berdasarkan hipotesis pengaruh variabel-variabel yang telah dijelaskan sebelumnya. Model penelitian dalam penelitian ini dimodifikasi dengan penggunaan TAM dalam penelitian penggunaan model layanan berbasis cloud computing pada penelitian terdahulu yang relevan sehingga terbentuklah model penelitian yang akan menguji 12 hipotesis seperti pada gambar I.

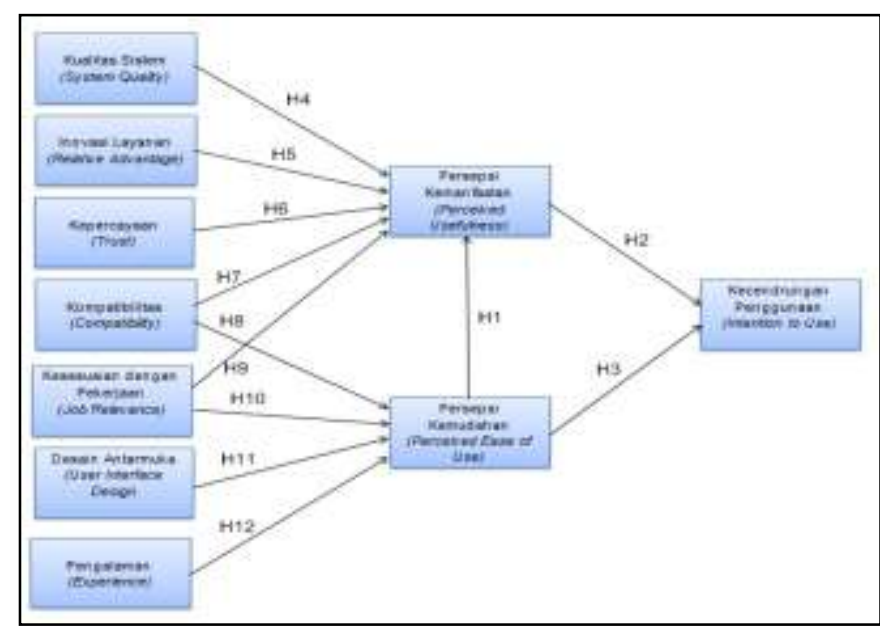

Gambar 1 Model Penelitian yang dikembangkan

$\mathrm{H}_{1}$ : Adanya hubungan signifikan antara Perceived Ease of Use dengan Perceived Usefulness

$\mathrm{H}_{2}$ :Adanya hubungan signifikan antara Perceived Usefulness dengan Intention to Use

$\mathrm{H}_{3}$ : Adanya hubungan signifikan antara Perceived Ease of Use dengan Intention to Use

$\mathrm{H}_{4}$ : Adanya hubungan signifikan antara System Quality berpengaruh terhadap Perceived Usefulness

$\mathrm{H}_{5}$ : Adanya hubungan signifikan antara Relative Advantage dengan Perceived Usefulness

$\mathrm{H}_{6}$ : Adanya hubungan signifikan antara Trust dengan Perceived Usefulness

$\mathrm{H}_{7}$ : Adanya hubungan signifikan antara Compatibility dengan Perceived Usefulness

$\mathrm{H}_{8}$ : Adanya hubungan signifikan antara Compatability dengan Perceived Ease of Use 
$\mathrm{H}_{9}$ : Adanya hubungan signifikan antara Job Relevance dengan Perceived Usefulness

$\mathrm{H}_{10}$ : Adanya hubungan signifikan antara Job Relevance dengan Perceived Ease of Use

$\mathrm{H}_{11}$ : Adanya hubungan signifikan antara User Interface Design dengan Perceived Ease of Use

$\mathrm{H}_{12}$ : Adanya hubungan signifikan antara Experience dengan Perceived Ease of Use

\section{METODOLOGI PENELITIAN}

\section{A. Definisi Operasional Variabel}

Penelitian ini menggunakan beberapa variabel eksternal yang diadopsi dari berbagai penelitian sebelumnya. Variabelvariabel tersebut diantaranya:

\section{System Quality}

System quality didefinisikan sebagai kualitas dari suatu kombinasi hardware dan software dalam sistem. Fokusnya adalah performa sistem yang merujuk pada seberapa baik kemampuan perangkat keras, perangkat lunak, kebijakan, prosedur dari sistem dapat menyediakan kebutuhan pengguna [12]. Indikator variabel yang akan digunakan dalam penelitian ini diambil dari penelitian Hamilton dan Charvany (1981) dalam [13], [14].

\section{Relative advantage}

Relative advantage diadopsi dari teori Diffusion of Innovative (DoI) oleh Roger. Dalam teori tersebut, Roger menjelaskan relative advantage sebagai: The degree to which innovation is perceived as being better than the idea it supersedes [15].Indikator variabel manifest yang akan digunakan dalam variabel ini diadospi dari penelitian yang dikembangkan oleh [16]-[18]

3. Trust

Trust berkaitan dengan kesediaan seseorang untuk berharap pada pihak lain dengan resiko tertentu ketika suatu suatu pihak percaya bahwa tindakan pihak lain akan memberikan hasil positif baginya. Hal ini dijelaskan oleh Mayer et al., yang mendefinisikan trust sebagai "The willingness of a party to be vulnerable to the actions of another party based on the expectation that the other will perform a particular action important to the trustor, irrespective of the ability to monitor or control the other party (Mayer, Davis, \& Schoorman, 1995:712). Beberapa penelitian terkait kepercayaan pada layanan cloud computing menunjukkan bahwa kepercayaan terutama pada provider penyedia layanan sangat berpotensi pada penerimaan layanan.

4. Compatibility

Keberhasilan suatu layanan juga sangat dipengaruhi oleh tingkat keserasian dari suatu inovasi apakah konsisten dan sesuai dengan nilai-nilai, pengalaman atau kebutuhan yang ada [20]. Dalam kasus cloud computing, hal ini diperlukan untuk memahami apakah teknologi ini kompatibel dengan arsitektur teknologi yang sudah ada. Hal ini juga diperlukan untuk memperhitungkan integrasi meliputi kenyamanan import dan export aplikasi dan kostumisasi [15], [18], [20]

5. Job Relevance
Job relevance didefinisikan sebagai persepsi individu terhadap suatu sistem dimana sistem tersebut dapat relevan dan dapat diaplikasikan pada pekerjaan seseorang [11]. Variabel job relevance ini diadopsi dari model TAM 2 oleh Venkatesh dan Davis.

\section{User Interface Design}

User interface menentukan seberapa mudah sebuah sistem memberikan respon terhadap perintah yang diberikan oleh pengguna. User interface bertujuan untuk membangun interaksi yang baik dan menyenangkan melalui kemudahan penggunaan, produktifitas dan kesenangan [21]. Hal ini juga berlaku dalam pengadopsian cloud computing terutama pada layanan software as a service Google Apps. User interface yang baik akan memudahkan user dalam menggunakan layanan. Penelitian Imam Yuadi menunjukkan bahwa kualitas antar muka sebuah sistem akan memberikan kontribusi penting dalam penggunaan sistem tersebut. Penelitian ini juga menemukan bahwa suatu cara atas informasi yang ditunjukkan pada layar mampu mempengaruhi strategi pencarian informasi pemakai sebagaimana kemampuannya [22].

\section{Experience}

Pengalaman atas penggunaan komputer secara umum dapat mempengaruhi keberhasilan interaksi dengan suatu program [23]. Berbagai kriteria telah diadopsi dalam berbagai kajian sebagai indikator atas pengalaman. Dalam konteks teknologi informasi, keterampilan komputer dan lama penggunaan harus dihitung karena mewakili pengalaman umum atas penggunaan komputer. Banyaknya pengalaman menggunakan komputer adalah ukuran yang objektif atas pengalaman pengguna komputer. Semakin banyak pengalaman komputernya berarti lebih besar eksposur ke berbagai jenis aplikasi dan tingginya tingkat keakraban dengan berbagai paket perangkat lunak.

TABEL I

RANGKUMAN ITEM PENGUKURAN

\begin{tabular}{|c|c|c|}
\hline Var. & Item & Pengukur \\
\hline \multirow[t]{4}{*}{ PEOU } & PEOU1 & $\begin{array}{l}\text { Layanan SaaS Google Apps memiliki fitur, } \\
\text { navigasi dan informasi yang mudah dipelajari }\end{array}$ \\
\hline & PEOU2 & $\begin{array}{l}\text { Layanan SaaS Google Apps memberikan } \\
\text { kemudahan berinteraksi bagi pengguna }\end{array}$ \\
\hline & PEOU3 & $\begin{array}{l}\text { Mudah bagi saya untuk menguasai penggunan } \\
\text { layanan SaaS Google Apps }\end{array}$ \\
\hline & PEOU4 & $\begin{array}{l}\text { Secara umum, saya merasa penggunaan layanan } \\
\text { SaaS Google Apps adalah mudah }\end{array}$ \\
\hline \multirow[t]{3}{*}{ PU } & PU1 & $\begin{array}{l}\text { Menggunakan layanan SaaS Google Apps } \\
\text { meningkatkan efektifitas pekerjaan saya }\end{array}$ \\
\hline & PU2 & $\begin{array}{l}\text { Menggunakan layanan SaaS Google Apps } \\
\text { meningkatkan produktifitas pekerjaan saya }\end{array}$ \\
\hline & PU4 & $\begin{array}{l}\text { Penggunaan layanan SaaS Google Apps sangat } \\
\text { membantu pekerjaan saya }\end{array}$ \\
\hline \multirow[t]{3}{*}{ ITU } & ITU1 & $\begin{array}{l}\text { Saya memilih untuk menggunakan layanan SaaS } \\
\text { Google Apps }\end{array}$ \\
\hline & ITU2 & $\begin{array}{l}\text { Saya berminat menggunakan layanan SaaS } \\
\text { Google Apps }\end{array}$ \\
\hline & ITU3 & $\begin{array}{l}\text { Saya ingin tetap menggunakan layanan SaaS } \\
\text { Google Apps }\end{array}$ \\
\hline SQ & SQ1 & $\begin{array}{l}\text { Layanan SaaS Google Apps mudah diakses } \\
\text { meskipun dilakukan perubahan desain } \\
\text { interface/tampilan menggunakan jenis browser } \\
\text { yang berbeda }\end{array}$ \\
\hline
\end{tabular}




\begin{tabular}{|c|c|c|}
\hline Var. & Item & Pengukur \\
\hline & SQ2 & $\begin{array}{l}\text { Layanan SaaS Google Apps meningkatkan } \\
\text { kecepatan akses terhadap berbagai kebutuhan } \\
\text { layanan }\end{array}$ \\
\hline & SQ3 & $\begin{array}{l}\text { Layanan SaaS Google Apps memiliki keandalan } \\
\text { yang tinggi sehingga jarang terjadi system down. }\end{array}$ \\
\hline & SQ4 & $\begin{array}{l}\text { Perlu dilakukan langkah-langkah pengamanan, } \\
\text { pengendalian dan pengawasan pada layanan SaaS } \\
\text { Google Apps }\end{array}$ \\
\hline \multirow[t]{3}{*}{ RA } & RA2 & $\begin{array}{l}\text { Layanan SaaS Google Apps memungkinkan saya } \\
\text { untuk meningkatkan layanan sesuai kebutuhan }\end{array}$ \\
\hline & RA3 & $\begin{array}{l}\text { Dengan menggunakan layanan SaaS Google } \\
\text { Apps, pengguna dapat mengakses informasi } \\
\text { dimana dan kapan saja }\end{array}$ \\
\hline & RA4 & $\begin{array}{l}\text { Performa layanan SaaS Apps tidak menurun } \\
\text { meskipun pengguna layanan bertambah. }\end{array}$ \\
\hline \multirow[t]{4}{*}{ CPT } & CPT1 & $\begin{array}{l}\text { Layanan SaaS Google Apps sesuai dengan } \\
\text { arsitektur komputer yang saya miliki }\end{array}$ \\
\hline & CPT2 & $\begin{array}{l}\text { Kustomisasi pada layanan SaaS Google Apps } \\
\text { dapat dilakukan dengan mudah }\end{array}$ \\
\hline & СРT3 & $\begin{array}{l}\text { Layanan SaaS Google Apps memungkinkan saya } \\
\text { melakukan ekstrak data dari cloud dengan mudah }\end{array}$ \\
\hline & CPT4 & $\begin{array}{l}\text { Upgrade yang dilakukan pada layanan SaaS } \\
\text { Google Apps tidak mengharuskan saya untuk ikut } \\
\text { meng-upgrade arsitektur komputer yang sudah } \\
\text { ada }\end{array}$ \\
\hline \multirow[t]{3}{*}{ JR } & JR1 & $\begin{array}{l}\text { Layanan SaaS Google Apps relevan dengan } \\
\text { kegiatan organisasi saya }\end{array}$ \\
\hline & JR2 & $\begin{array}{l}\text { Penggunaan layanan SaaS Google Apps dalam } \\
\text { pekerjaan saya sangat penting }\end{array}$ \\
\hline & JR3 & $\begin{array}{l}\text { Untuk kebutuhan masa depan organisasi, layanan } \\
\text { SaaS Google Apps sangat diperlukan }\end{array}$ \\
\hline \multirow[t]{4}{*}{$\begin{array}{l}\text { TRUS } \\
\text { T }\end{array}$} & TRUST1 & $\begin{array}{l}\text { Saya percaya pada penyedia layanan SaaS } \\
\text { Google Apps karena merupakan vendor } \\
\text { terpercaya dan professional }\end{array}$ \\
\hline & TRUST2 & $\begin{array}{l}\text { Penyedia layanan SaaS Google Apps adalah } \\
\text { vendor yang menjaga janji dan komitmen dalam } \\
\text { pelayanannya }\end{array}$ \\
\hline & TRUST3 & $\begin{array}{l}\text { Saya percaya penyedia layanan SaaS Google } \\
\text { Apps memiliki kebijakan yang mengatur } \\
\text { keamanan data pribadi pengguna. }\end{array}$ \\
\hline & TRUST4 & $\begin{array}{l}\text { Secara umum, layanan SaaS Google Apps dapat } \\
\text { dipercaya }\end{array}$ \\
\hline \multirow[t]{3}{*}{ UI } & UI2 & $\begin{array}{l}\text { Pemilihan warna dan tata letak antarmuka } \\
\text { layanan SaaS Google Apps membuat saya } \\
\text { nyaman menggunakannya. }\end{array}$ \\
\hline & UI3 & $\begin{array}{l}\text { Antarmuka layanan SaaS Google Apps sangat } \\
\text { interaktif }\end{array}$ \\
\hline & UI4 & $\begin{array}{l}\text { Secara umum saya puas dengan antarmuka } \\
\text { layanan Google Apps }\end{array}$ \\
\hline \multirow[t]{3}{*}{ EX } & EX2 & $\begin{array}{l}\text { Saya sering menggunakan layanan SaaS Google } \\
\text { Apps }\end{array}$ \\
\hline & EX3 & $\begin{array}{l}\text { Saya memiliki pengetahuan tentang layanan SaaS } \\
\text { Google Apps }\end{array}$ \\
\hline & EX4 & $\begin{array}{l}\text { Saya memiliki pengalaman menggunakan } \\
\text { layanan layanan SaaS Google Apps }\end{array}$ \\
\hline
\end{tabular}

B. Desain Penelitian

Populasi dalam penelitian ini adalah mahasiswa Politeknik TEDC Bandung dari jurusan Teknik Komputer dan Informatika jenjang DIII dan DIV, kelas reguler, beasiswa dan kelas karyawan angkatan tahun 2012, 2013, 2014 dan 2015. Penulis memperoleh data jumlah mahasiswa jurusan Teknik Komputer dan Informatika kelas reguler, beasiswa dan kelas karyawan ini sebanyak 323 orang. Penentuan sampel menggunakan rumus Slovin yang dikutip dari [24] dengan tingkat kepercayaan 95\% dan tingkat error 5\% sehingga diperoleh ukuran sampel sebanyak 179 orang. Data diperoleh dengan menyebar kuesioner yang terdiri dari 34 butir pertanyaan kepada 200 orang responden. Jumlah responden ini sengaja dilebihkan dari ukuran sampel awal untuk menghindari kuesioner yang kembali dalam keadaan tidak valid, jilang, rusak dan tidak lengkap.

\section{Pengumpulan Data}

Penyebaran kuesioner dilakukan pada minggu keempat bulan Oktober dilanjutkan minggu ke dua bulan November 2015 dikarenakan pada minggu pertama bulan November adalah minggu Ujian Tengah Semester sehingga tidak dilakukan penyebaran kuesioner. Kuesioner yang kembali dan terisi dengan lengkap adalah sebanyak 194 kuesioner. Enam kuesioner dinyatakan tidak lengkap, dua diantaranya tidak memiliki data identitas responden dan selebihnya berisi butir kuesioner yang tidak diisi dengean lengkap. Dari 194 kuesioner dilakukan pemilahan lagi untuk mengeluarkan kuesioner yang memiliki nilai ekstrim. Dari hasil pemilahan diperoleh 4 kuesioner dengan nilai ekstrim sehingga harus dieliminasi. Hasil akhir kuesioner yang lengkap dan memenuhi standar untuk di olah lebih lanjut adalah sebanyak 190 kuesioner.

\section{Analisis data}

Data yang diperoleh selanjutnya diolah dengan bantuan software SPSS 20. Pengujian model pengukuran dan struktural menggunakan model analisis faktor konfirmasi dengan aplikasi AMOS 22. Analisis diawali dengan melakukan pengujian model pengukuran (measurement model) satu faktor untuk mengukur tingkat signifikansi setiap indikator apakah mendukung variabelnya. Setelah dilakukan pengujian model pengukuran, selanjutnya dilakukan pengujian struktural yang melibatkan keseluruhan variabel dan menguji fit model berdasarkan kriteria goodness of fit.

\section{IV.HASIL DAN PEMBAHASAN}

\section{A. Profil Responden}

Secara umum, demografis responden dapat terlihat pada tabel 2. Penelitian di dominasi oleh responden lelaki sebanyak 143 orang $(75,3 \%)$ dan responden perempuan hanya 47 orang $(24,7 \%)$. Responden terbanyak berasal dari jurusan Teknik Kompuer dan Informatika Reguler DIV sebanyak 90 orang $(47,4 \%)$. Jika di klasifikasikan berdasarkan angkatan, maka responden terbanyak berasal dari angkatan 2015 sebanyak 57 orang (30\%) namun jumlah ini cukup berimbang dengan jumlah responden dari angkatan yang lain. Pola penggunaan layanan terlihat dari frekuensi penggunaan layanan. Sebanyak 113 responden $(59,5 \%)$ hanya menghabiskan 2-3 kali dalam seminggu untuk mengakses layanan, jumlah ini lebih tinggi dibanding yang lainnya dan responden lebih banyak menghabiskan 2-3 jam untuk mengakses layanan yaitu sebanyak 92 orang $(48,4 \%)$. 
TABEL II

PROFIL RESPONDEN

\begin{tabular}{|c|c|c|c|}
\hline \multicolumn{2}{|l|}{ Profil Responden } & \multirow{2}{*}{$\begin{array}{l}\text { Frekuensi } \\
190\end{array}$} & \multirow{2}{*}{$\begin{array}{l}\text { Persentasi } \\
(\%) \\
100\end{array}$} \\
\hline Jumlah Responden & & & \\
\hline Jenis Kelamin & Perempuan & 47 & 24,7 \\
\hline & Lelaki & 143 & 75,3 \\
\hline \multirow[t]{5}{*}{ Jurusan } & Reg DIII & 29 & 15,3 \\
\hline & Reg DIV & 90 & 47,4 \\
\hline & Bea DIV & 15 & 7,9 \\
\hline & Kar DIII & 8 & 4,2 \\
\hline & Kar DIV & 48 & 25,3 \\
\hline \multirow[t]{4}{*}{ Angkatan } & 2012 & 34 & 17,9 \\
\hline & 2013 & 44 & 23,2 \\
\hline & 2014 & 55 & 28,9 \\
\hline & 2015 & 57 & 30 \\
\hline \multirow[t]{4}{*}{ Frek. Penggunaan } & Sekali & 18 & 9,5 \\
\hline & 2-3 Kali & 113 & 59,5 \\
\hline & 4-5 Kali & 29 & 15,3 \\
\hline & HampirSetiap hari & 30 & 15,8 \\
\hline \multirow[t]{5}{*}{ Lama Penggunaan } & $<1 \mathrm{Jam}$ & 7 & 3,7 \\
\hline & 2-3 jam & 92 & 48,4 \\
\hline & 5-8 Jam & 66 & 34,7 \\
\hline & 8-10 Jam & 20 & 10,5 \\
\hline & $>10 \mathrm{Jam}$ & 5 & 2,6 \\
\hline
\end{tabular}

B. Hasil Pengujian

Hasil pengujian menggunakan Structural Equation Modeling (SEM) terhadap model penelitian yang diajukan menunjukkan hasil berupa hubungan yang signifikan maupun tidak signifikan antar variabel dan model fit penelitian berdasarkankriteria goodness of fit

TABEL III

PROFIL RESPONDEN

\begin{tabular}{|c|c|c|}
\hline Kriteria Model Fit & Hasil Uji & Level Penerimaan \\
\hline Chi Square (CMIN) & 1218,69 & $\begin{array}{l}\text { Diantara CMIN saturated Model } \\
\text { dan CMIN Independence model } \\
{[25]}\end{array}$ \\
\hline $\begin{array}{l}\text { Goodness of Fit Index } \\
\text { (GFI) }\end{array}$ & 0,760 & $\begin{array}{l}\text { Berkisar 0 sampai } 1 \\
\text { (mendekati } 1 \text { akan semakin } \\
\text { baik) [25] }\end{array}$ \\
\hline Adjusted GFI (AGFI) & 0,706 & $\begin{array}{l}\text { Berkisar 0 sampai } 1 \\
\text { (mendekati } 1 \text { akan semakin } \\
\text { baik) [25] }\end{array}$ \\
\hline $\begin{array}{l}\text { Root-mean-Square error of } \\
\text { Approximation (RMSEA) }\end{array}$ & 0,089 & $<0,08[25]$ \\
\hline Tucker-Lewis Index (TLI) & 0,535 & $\begin{array}{l}\text { Berkisar } 0 \text { sampai } 1 \\
\text { (mendekati } 1 \text { akan semakin } \\
\text { baik) Angka TLI bisa di bawah } \\
0 \text { dan di atas } 1 \text { [25] }\end{array}$ \\
\hline Normed Fit Index (NFI) & 0,489 & $\begin{array}{l}\text { Berkisar 0 sampai } 1 \\
\text { (mendekati } 1 \text { akan semakin } \\
\text { baik) [25] }\end{array}$ \\
\hline $\begin{array}{l}\text { Confirmatory Fit Index } \\
\text { (CFI) }\end{array}$ & 0,598 & $\begin{array}{l}\text { Berkisar 0 sampai } 1 \\
\text { (mendekati } 1 \text { akan semakin } \\
\text { baik) }[25]\end{array}$ \\
\hline $\begin{array}{l}\text { Parcimonious Fit Index } \\
\text { (PNFI) }\end{array}$ & 0,423 & $\begin{array}{l}\text { Berkisar 0 sampai } 1 \\
\text { (mendekati } 1 \text { akan semakin } \\
\text { baik) }[25]\end{array}$ \\
\hline
\end{tabular}

Dari 12 hipotesis yang diajukan, 8 hipotesis dapat diterima dan 4 diantaranya ditolak berdasarkan hasil uji struktural dengan structural equation modeling. Pengujian hipotesis pada penelitian ini dilakukan dengan membandingkan $p$-value pada tabel regression weights dengan taraf signifikan $\alpha=5 \%$. Jika nilai kolom P lebih kecil dari 0,05 menunjukkan koefisien jalur (relasi dependensi) yang bersangkutan signifikan $\left(\mathrm{H}_{0}\right.$ ditolak dan $\mathrm{H}_{1}$ diterima). Tiga buah asterik (***) pada kolom $\mathrm{P}$ menunjukkan bahwa $p$-value yang dihasilkan sangat kecil dari 0,001 [26].

Hasil menunjukkan bahwa Trust tidak berpengaruh signifikan terhadap Perceived Ease of Use, begitu pula compatibility tidak berpengaruh signifikan baik terhadap Perceived Ease of Use maupun Perceived Usefulness. Selain itu Perceived Ease of Use juga tidak berpengaruh signifikan terhadap Intention to Use.

TABEL IV

HASIL PENGUJIAN HIPOTESIS

\begin{tabular}{|l|l|l|l|}
\hline No & Hipotesis & $\begin{array}{l}\text { P- } \\
\text { Value }\end{array}$ & Keterangan \\
\hline 1 & $\begin{array}{l}\text { Adanya hubungan signifikan antara } \\
\text { Perceived Ease of Use dengan } \\
\text { Perceived Usefulness }\end{array}$ & 0,035 & Signifikan \\
\hline 2 & $\begin{array}{l}\text { Adanya hubungan signifikan antara } \\
\text { Perceived Usefulness dengan Intention } \\
\text { to Use }\end{array}$ & 0,001 & Signifikan \\
\hline 3 & $\begin{array}{l}\text { Adanya hubungan signifikan antara } \\
\text { Perceived Ease of Use dengan } \\
\text { Intention to Use }\end{array}$ & 0,806 & Tidak Signifikan \\
\hline 4 & $\begin{array}{l}\text { Adanya hubungan signifikan antara } \\
\text { System Qualityberpengaruh terhadap } \\
\text { Perceived Usefulness }\end{array}$ & 0,006 & Signifikan \\
\hline 5 & $\begin{array}{l}\text { Adanya hubungan signifikan antara } \\
\text { Relative Advantage dengan Perceived } \\
\text { Usefulness }\end{array}$ & 0,004 & Signifikan \\
\hline 6 & $\begin{array}{l}\text { Adanya hubungan signifikan antara } \\
\text { Trust dengan Perceived Usefulness }\end{array}$ & 0,217 & Tidak Signifikan \\
\hline 7 & $\begin{array}{l}\text { Adanya hubungan signifikan antara } \\
\text { Compatibility dengan Perceived } \\
\text { Usefulness }\end{array}$ & 0,663 & Tidak Signifikan \\
\hline 8 & $\begin{array}{l}\text { Adanya hubungan signifikan antara } \\
\text { Compatability dengan Perceived Ease } \\
\text { of Use }\end{array}$ & 0,337 & Tidak Signifikan \\
\hline 9 & $\begin{array}{l}\text { Adanya hubungan signifikan antara } \\
\text { Job Relevance dengan Perceived } \\
\text { Usefulness }\end{array}$ & 0,029 & Signifikan \\
\hline 10 & $\begin{array}{l}\text { Adanya hubungan signifikan antara } \\
\text { Job Relevance dengan Perceived Ease } \\
\text { of Use }\end{array}$ & $* * *$ & Signifikan \\
\hline 11 & $\begin{array}{l}\text { Adanya hubungan signifikan antara } \\
\text { User Interface Design dengan } \\
\text { Perceived Ease of Use }\end{array}$ & $* * *$ & Signifikan \\
\hline 12 & $\begin{array}{l}\text { Adanya hubungan signifikan antara } \\
\text { Experience dengan Perceived Ease of } \\
\text { Use }\end{array}$ & 0,005 & Signifikan \\
\hline & \multicolumn{1}{|c|}{ Han } & & \\
\hline
\end{tabular}

\section{KESIMPULAN}

Pada penelitian ini variabel Perceived Ease of Use tidak berpengaruh signifikan terhadap Intention to Use. Hal ini terlihat dari frekuensi dan lama penggunaan layanan yang rendah. Variabel Trust tidak berpengaruh secara signifikan terhadap Perceived Usefulness karena pengguna mempertimbangkan alasan keamanan data yang mereka miliki, selain itu pengguna tidak memahami kebijakan keamanan yang ada sehingga tidak mempengaruhi kemanfaatan layanan. Variabel Compatibility tidak berpengaruh terhadap Perceived 
Usefulness dikarenakan layanan ini memerlukan arsitektur komputer yang terhubung dengan koneksi internet sepenuhnya, sedangkan pengguna tidak setiap saat terhubung dengan layanan internet. Variabel Compatibility juga tidak berpengaruh signifikan terhadap Perceived Ease of Use karena layanan yang diakses melalui perangkat mobile menuntut pengguna untuk memiliki perangkat mobile dengan spesifikasi menengah ke atas karena cukup menguras memori dan penyimpanan terlebih jika layanan mengalami pembaharuan versi.

\section{REFERENSI}

[1] M. Cooney, "Gartner: The Top 10 Strategic Technology Trends for 2012," 2011. [Online]. Available:

http://www.networkworld.com/article/2182273/infrastructuremanagement/gartner--the-top-10-strategic-technology-trends-for2012.html. [Accessed: 25-Jun-2015].

[2] P. High, "Gartner: Top 10 Strategic IT Trends For 2015," 2014. [Online]. Available:

http://www.forbes.com/sites/peterhigh/2014/10/07/gartner-top-10strategic-it-trends-for-2015/. [Accessed: 25-Jun-2015].

[3] H. Gunawan, "Menjawab Tantangan Fenomena Big Data di Indonesia," Tribuntechno, 2012. [Online]. Available: http://www.tribunnews.com/iptek/2012/11/23/menjawab-tantanganfenomena-big-data-di-indonesia. [Accessed: 13-Sep-2015].

[4] Afdhal, "Studi Perbandingan Layanan Cloud Computing," J. Rekayasa Elektr., vol. 10, no. 4, pp. 193-201, 2013.

[5] B. Sosinsky, Cloud Computing Bible. 2011.

[6] W. Hidayat, "9 Tips Memanfaatkan Google Apps untuk Mahasiswa," Kompas, 2012. [Online]. Available: http://tekno.kompas.com/read/2012/11/05/14070471/9.tips.memanfaatk an.google.apps.untuk.mahasiswa. [Accessed: 13-Sep-2015].

[7] Meruvian, "Mengembangkan Solusi Cloud dengan PaaS." Jakarta, pp. $1-75,2012$.

[8] H. Qi and A. Gani, "Research on Mobile Cloud Computing : Review , Trend and Perspectives," 2014.

[9] A. Susilo and Yasmiati, "Google Apps untuk Proses Pembelajaran di Fakultas Teknologi Informasi (FTI) Universitas Respati Indonesia," Semin. Nas. Apl. Teknol. Inf. 2011, no. Snati, pp. 23 - 28, 2011.

[10] A. Wibowo, "Kajian tentang Perillaku Pengguna Sistem Informasi," Universitas Budi Luhur, 2009.

[11] V. Venkatesh and F. D. Davis, "A Theoritical extention of the thechnology acceptance model : four longitudinal field study," Manag. Sci., vol. 46, no. 2, pp. 186-204, 2000.
[12] W. H. DeLone and E. R. McLean, "Information System Success: The Quest for the Dependent variabel," Inf. Syst. Res., 1992.

[13] A. Kusumawati, A. Pribadi, and M. A. Hanim, "Analisis Kualitas Sistem Informasi Terhadap Peningkatan Produktivitas dan Pengetahuan Mahasiswa Sebagai Pengguna Media Pembelajaran Berbasis Elearning," J. Tek. POMITS, pp. 1-8, 2003.

[14] D. Radityo, "Pengujian Model DeLone and McLean Dalam Pengembangan Sistem Informasi Manajemen ( Kajian Sebuah Kasus )," Simp. Nas. Akunt. X, pp. 1-25, 2007.

[15] M. Stieninger, D. Nedbal, W. Wetzlinger, G. Wagner, and M. a. Erskine, "Impacts on the Organizational Adoption of Cloud Computing: A Reconceptualization of Influencing Factors," Procedia Technol., vol. 16, pp. 85-93, 2014.

[16] G. Feuerlicht and S. Govardhan, "Impact of Cloud Computing: Beyond a technology Trend," in In the Proceeedings of the International Conference on System Integration, 2010, pp. 1-8.

[17] P. Geczy, N. Izumi, and H. Koiti, "Cloudsourcing: Managing Cloud Adoption," Glob. J. Bus. Res., vol. 6, no. 2, pp. 57-70, 2012.

[18] H. Gangwar and R. Ramaswamy, "Understanding Determinants of Cloud Computing Adoption using an Integrated TAM-TOE Model," $J$. Enterp. Inf. Manag., vol. 28, no. 1 pp, 2013.

[19] R. C. Mayer, J. H. Davis, and F. D. Schoorman, “An Integrative Model of Organizational Trust," Acad. Manag. Rev., vol. 20, no. 3, pp. 709734, 1995.

[20] F. Calisir, C. Gummusoy, and A. Bayram, "Predicting the Behavioral Intention to Use Enterprise Resource Planning System: An Exploratory Extension of The Technology Acceptance Model," Manag. Res. News, vol. 32, no. 7, pp. 597-613, 2009.

[21] W. O. Galitz, The Essential Guide to An Introduction to GUI Design Principles and Techniques, 2nd Editio. Canada: Wiley Computier Publishing, 2002.

[22] I. Yuadi, "Analisis Technology Acceptance Model terhadap Perpustakaan Digital dengan Structural Equation Modeling Oleh Imam Yuadi Departemen Ilmu Informasi dan Perpustakaan,” Dep. Ilmu Inf. dan Perpust., 2009.

[23] M. Igbaria, T. Guimaraes, and G. B. Davis, "Testing The Determinants of Micro computer usage via a Structural Equation Model," J. Manag. Inf. Syst., vol. 11, no. 4, pp. 87-114, 1995.

[24] V. W. Sujarweni, Belajar Mudah SPSS Untuk Penelitian Skripsi, Tesis, Disertasi \& Umum,. Yogyakarta: Global Media Informasi, 2008, p. 10

[25] S. Santoso, Structural Equation Modeling (SEM) Konsep dan Aplikasi dengan AMOS 22. jakarta: PT. Elex Media Komputindo Kompas Gramedia, 2014.

[26] U. Dachlan, Panduan Lengkap Structural Equation Modeling, 1st Editio. Semarang: Lentera Ilmu, 2014. 